Alexander A. Chibilev' ${ }^{1}$, Sergey V. Bogdanov ${ }^{2 *}$, Murat N. Sdykov ${ }^{3}$

${ }^{1}$ Institute of Steppe of the Urals branch of the RAS, Pionerskaya st. 11, 460000,

Orenburg, Russia; tel./fax: (3532) 774432; e-mail: orensteppe@mail.ru

$2^{*}$ Laboratory of historic cultural and natural heritage, Institute of Steppe of the Urals branch of the RAS, Pionerskaya st. 11, 460000, Orenburg, Russia; tel./fax: (3532) 774432; e-mail: bogdanov-step@yandex.ru (Corresponding author)

${ }^{3}$ Western Kazakhstan Center for the History and Archaeology, Dostyk-Druzhby st. 194, 208, Uralsk, Kazakhstan Republic; tel. (7112) 503578, 515226; e-mail: msdykov@mail.ru

\title{
THE PHENOMENON OF THE HISTORICAL-GEOGRAPHICAL CONTINUITY OF NOMADIC EMPIRES IN EURASIAN STEPPES
}

\begin{abstract}
The article summarizes large volume of historical and geographical data on the influence of nomadic peoples on the landscapes of northern Eurasian steppe during the pre-agricultural phase, i.e. prior to the 18-19th centuries. It was concluded that landscapes of the steppe belt represented natural-anthropogenic complexes resulting from cultural transformation of the area by nomadic peoples. The article addresses the key issues facing a new field of study called steppe science.
\end{abstract}

KEY WORDS: historical-geographical continuity, empires of nomads, dynamics of development, ecological situations.

\section{INTRODUCTION}

Geographical and socio-cultural prerequisites for the formation of nomadic empires

The steppe landscape zone played an important role in the history of Eurasia, Russia, and, in the final analysis, the Old World during many centuries. The ethnogenesis of the greater part of Northern Eurasia's peoples is connected with historical-geographicalspace of the steppes. Starting in the Early Metal
Age (V - early II millennia B.C.), the steppe and forest-steppe of the continent became the cradle of nomadic animal husbandry. Horses and cattle were domesticated in the steppes of Northern Eurasia before the IV millennium B.C. Small-size stock breeding culture was introduced from the outside, i.e., from the territory of the Near East. At the turn of the IV millennium B.C., the wheel for transport emerged and the copper deposits on the Northern Donets river and in the Priuralia were exploited. [Bogdanov, 2004; Merpert, 1974; Ryndina, Degtyareva, 2002; Chernykh, 2007]. According to the geological scale, these impressive innovations in the milieu of steppe inhabitants, all refer to the turning-point in the natural history of Northern Eurasia: during the Mid-Holocene the boreal-type cold steppes were replaced everywhere by steppe landscapes of the modern type. Subsequently, there were periods of cold and warm aridization, but no global changes in natural-climatic conditions were recorded. The transition to nomadic animal husbandry was favored, first, by the development of steppe population, second, by the climatic changes toward aridization, and, third, by the intensive use of wheeled transport, by domestication of horses for riding purposes, and by extensive pursuits of 
horse-breeding. Intensive nomadic animal husbandry furnished an opportunity to make the most use of the natural resources of the steppes, which was beneficial for obtaining surplus produce, promoting the exchange of goods and the social differentiation in tribes, and for the emergence of preconditions for formation of statehood.

The transition to nomadic animal husbandry and lifestyle resulted in dramatic changes of the steppes. The impact on the nature by Stone Age tribes was distributed between their seats and included river valleys and lakesides, where settlements of on-ground and deepened dwellings were concentrated near fishery sites, drinking places, and migratory paths of wild ungulates. The use of steppe bio-resources was extremely selective. Nomadic peoples influenced the steppe all over. The nomadic lifestyle, unlike the settled one, means the high extent of the territory use. All the territory is involved into the economy use zone. This is why nomads developed the classification of space by their suitability to be occupied and be involved in economy [Nanzatov et al., 2008]. The mobility of nomadic tribes and permanent rout of better pastures caused frequent military conflicts which were accompanied by the burning of steppe. The nomadic lifestyle of steppe peoples promoted their contacts with settled farmers of the Far East, the Middle Asia, the Caucasus, and the Central Europe and promoted the emergence of poly-ethnic "symbioses" of nomadic and settled populations. Since the Early Metal Age, the steppe, for five millennia, was developing under the influence of anthropogenic factors, such as the burning of vegetation for military, hunting, and agrarian purposes, wiping out wild ungulates all over, livestock pasturing changeable in space and time, progressing exploitation of mineral deposits.

The mobility of nomads was determined not only by the dominant economycultural type, but also by very specific social phenomena formed in the early Metal Age in V-III millennia B.C. and existed in various modifications till the New Age. They are: blood feud (vendetta); mass practice of "adoption", which was the modification of "amanatment" (taking hostage); the tradition of sworn brotherhood, united young warrior bands; "baltsy" (Iranian) or "baranta" (Turkic) in the form of plundering raids on lands of neighbor clans aimed at abaction, bride kidnapping, and acquisition of property valuable at that epoch. If the forces of "baltsy" participants and their opponents were in parity or violence was unreasonable, young warriors could be hired as shepherds for a long enough time, one year or more, to earn what they could not take away by their force. Essentially, returning with loot was the main social motivation, while means of taking the loot were not principal. This was the main ethic difference between the norms of nomads and the ethics of settled farmers. Abaction and any form of robbery are strongly condemned by farming cultures and civilizations, but they are considered outstanding valor by nomads. In tote, very close social-cultural, economical, and other traditions formed in Eurasian steppes homogeneous enough, plastic and dynamic continuums of nomads that were permanently in the state of transitive reforming. Instability of these formations that had historical trend to occupy all the area of steppes of Northern Eurasia was caused by the transitivity and other qualitative characteristics of nomad societies.

Meanwhile, displacements of culturalhistorical traditions and population in the Great Steppe were occurring there in certain directions: from arid regions of extreme environment to more favorable ecological niches of temperate continental climate or environment close to semiarid Mediterranean subtropics. Translations of cultural achievements took place in three historical modes coexisting for the last six millennia. A slow enough spreading of a nomad group to free ecological niches accompanied with the spread of their language and local traditions of material and spiritual culture, corresponded to effusions. Diffusions took place through the spread of 
local traditions to neighbors in direct contacts (marriages, "baranta"-"baltsy", territorial conflicts, "adoption", gift exchange, trade exchange, etc.). Migrations of large groups of nomads, evoked by ecological, political, social, and other causes corresponded, as a rule to transfusions.

\section{THE FIRST NOMADIC EMPIRES IN THE GEOGRAPHIC AREA OF STEPPES}

It is accepted that nomadic lifestyle existed in two variants: the one with year-round moving and the one with settled winter quarters (semi-settled semi-nomadic). Despite the fact that year-round nomads left virtually nothing for the modern archaeology, we have strong reasons to believe that traces of their existence can be encountered everywhere. Temporary used sites rarely led to the formation of a developed cultural layer, but the sites promoted foci of digression of pasture vegetation, intensification of erosion and aeolian processes, conversion of natural vegetation into synanthropic, and also direct extermination of animal species that were dangerous or competitive to that economiccultural type of nomadic stock-breeders. Besides burial complexes, that are well visible in field and plotted on topographic maps, thousands of simple burial places remain unknown. Many unusual forms of microrelief are still not identified, such as unnatural piles of stones known as "obo", "gurias", small fences, cromlechs, et al.

The environment of steppe was even more affected by the nomadism applying settled winter quarters and, in some regions, summer quarters. The development of farming and handicraft often turned these quarters into settlements, so called headquarters, for a certain period. At the beginning of the early Iron Age (VIII-VII centuries B.C.) overall steppes of Northern Eurasia from Mongolia in the east to the Danube river in the west, a largely homogenous continuum of Iran-speaking Scythian tribes ("ishcusa" in texts from Near East) was formed. The fragile balance of this socio-cultural system was often broken by emergence of a charismatic leader, who could join several "field commanders", or by a local natural disaster: a dzut (mass starvation of livestock in winter due to ice coating on winter pastures), an epidemic, etc. In the late VII B.C., a large group of Iranspeaking nomads from Northern Eurasia headed by one of such leaders, king Madius the son of Prototius, invades Western Asia, defeated Urartu and Midia, and conqured the entire Near East. The empire of Madius proved to be ephemeral as all subsequent nomadic empires as well. After 28 years of existence, it broke up and Scythians came back homeland divided into groups by clan and tribe and carrying their loot [Dovatur et al., 1982]. Such ephemeral pseudo-states were emerging among nomads of Northern Eurasia during the entire early Iron Age (VIII century B.C. - IV century A.D.), but the history unfortunately do not know names of these states and their rulers.

According to G.V. Vernadsky, open landscapes of steppes and deserts, much like sea, promoted the trading and cultural relations between relatively isolated regions of sedentary agricultural culture of Eurasia (China, Khorezm, and the Mediterranean countries) [Vernadsky, 1927]. It is the nomads that constituted the mobile human element, external factor, that, on a regular basis, introduced changes into ethnic and anthropological diversity of the population living in Inner, Central, and Western Asia, Russia, and in most of Europe [Adji, 1998; Mordkovich, 2007; Krivosheyev, 2006].

In the IV and II centuries B.C. the Scythian cultural heritage was altered by the Sarmatians and the Sauromatians in the Black Sea-Caspian steppe region, by the Kushans in Central Asia, and by the Huns in Inner Asia and Southern Siberia [Klyashtorny, Savinov, 2005]. At that time in the east of the Eurasian steppes, in opposition to the Imperial Chinese Qin Dynasty (230-221 B.C.), there emerged a political confederation of nomadic tribes, the Xiongnu, which was termed by G.V. Vernadsky [Vernadsky, 1927], O. Janse [Janse, 1935], and R. Grousset [Grousset, 1939] the Steppe Empire, implying 
the ideas of the specific state formations of the nomads that occupied the geographical space of the "Great Steppe". The Chinese State responded to the rise of the Xiongnu Steppe Empire with the construction of the Great Wall of China (214 B.C.). Over the course of nearly two millennia, the sedentary civilizations of Eurasia were continually attempting to shut themselves off from their disturbing neighbors using "anti-steppe" protective fortification lines, namely the ramparts and fortifications built by Prince Vladimir (X century A.D.), the Tula abatis line, the Belgorod line, the Cossack defense fortification lines, the "Perovsky rampart" in Transuralia, etc. P.N. Savitsky [1927] was the first to carry out a landscape-historical analysis of the Eurasian fortification ("border") lines.

The Xiongnu Empire united the territories of Manchuria, Mongolia, Dzhungaria, and the Baikal region for about two centuries; however, because of constant war conflicts, both with China and with other nomadic peoples, in the early I century B.C., it fell into decay. As the result of migration of Turkic tribes to Eastern Kazakhstan and Zhetysu (Seven rivers' basin) as well as to the UralCaspian steppes, there emerged war-political unions of the Hunnic, Sarmatian, and the Ugric tribes. In the 70s of the 4th century A.D., a new European nomadic empire, the Hunnic Empire, was created by Attila the Hun on the eastern borders of the Roman Empire.

The next epoch of steppe empires is associated with the establishment of Turkic Khaganates (Fig. 1). The first Turkic Khaganate was founded in 552. This was followed by the creation of the Western and Eastern Turkic Khaganates, with the Second Turkic Khaganate established in 682, after their disintegration. These nomadic state formations encompassed the belt of mountain and plain steppes from the Sungari basin and the Great Wall of China in the east to Azov region and Northern Crimea in the west.

Arabian authors, who learned about Turki from participants of campaigns to Turan
(Turkestan), saved a number of distinctive descriptions of customs and morals of nomads, inhabitants of warlike Turkic Khaganate. This is what is written by AlDzhakhiza, the erudite from Bagdad (died in 869), wrote the following aboutTurkic lifestyle, "Turki are of peoples for whom a settled life, an unmoving state, a long-time being in one and the same place, low number of moves and changes are intolerable. The gist of their constitution is based on moving, and there is no predestination of peace for them... They do not practice any handicraft, trade, medicine, farming, horticulture, construction, canal building, or crop gathering. And they have no business but robbery, raid, hunting, horseback riding, battles of warriors, loot rout, and conquest of countries... A Turki shoots at wild animals, birds, shooting marks, people... He shoots from his horse rushing nip and tuck forward and backward, rightward and leftward, upward and downward. He shoots out ten arrows before a kharidzhit [an Arab] puts one arrow to his bow string" [Klyashtorny, Savinov, 2005, p.106].

Nomadic animal husbandry constituted the main sector of the economy pursued by the Turki, and by the neighboring peoples. They were engaged in sheep, horse, camel, and yak breeding. Prominent, among the pursuits of the ancient Turki, was hunting wild horses, zerens (Mongolian gazelles), Altai wapiti (Siberian elk), Alpine ibex, roe, sable, squirrel, and marmots. In many areas of Southern Siberia, there existed centers of mining and working of iron. A well developed road network emerged between these settlements and nomadic headquarters. Hence, it can be concluded that the Great Steppe at the time of the Turkic Khaganates, was experiencing much more serious human impacts than previously.

After the fall of the Turkic Khaganates (the Second Turkic Khaganate ceased its existence in 744) in the XI - early XII centuries, the steppes of Eurasia, as before, were dominated by a nomadic lifestyle (as pursued by the Karluks, Pechenegs, Kypchaks, and Mongols). On the other hand, there were emerging 

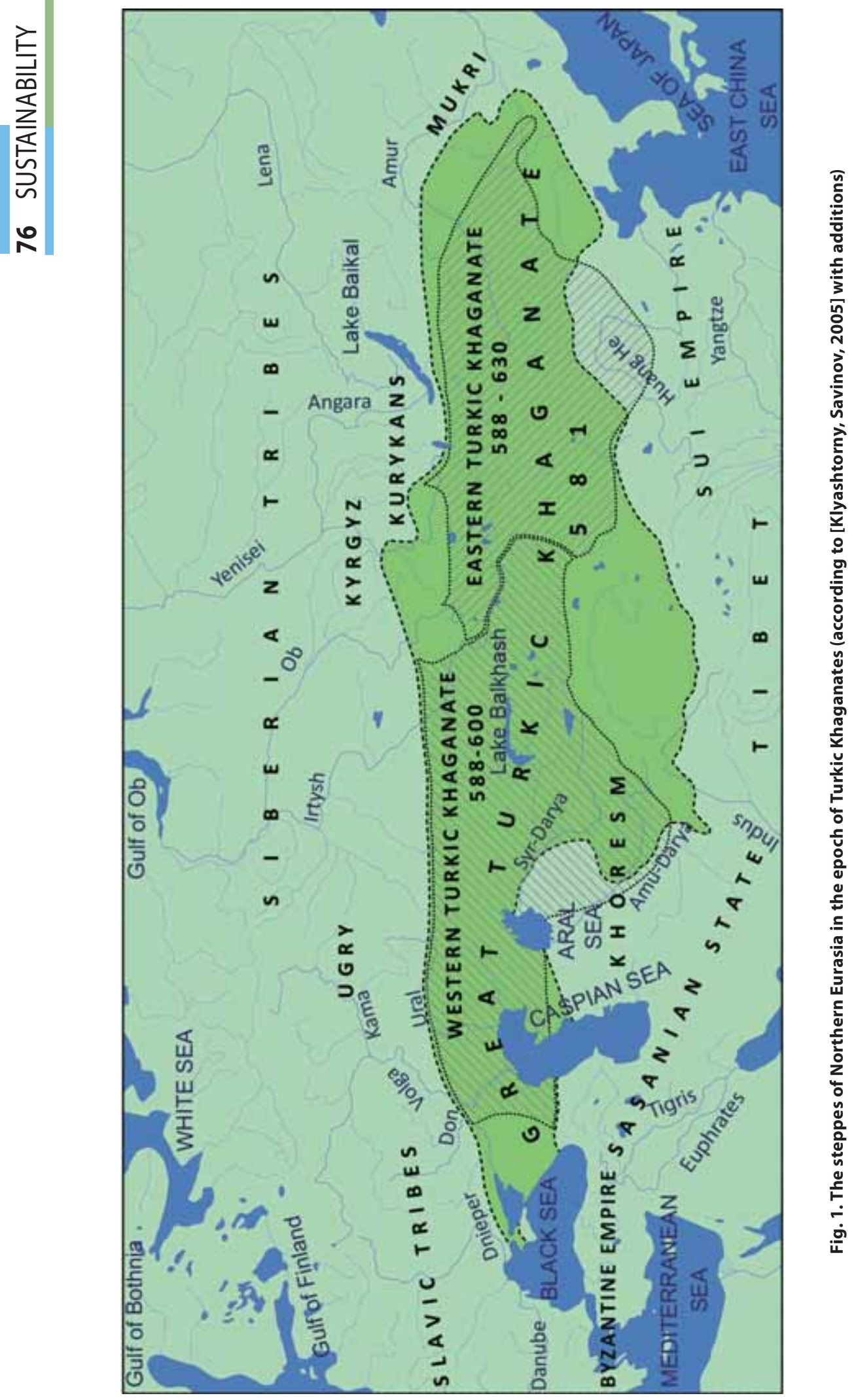
centers with an integrated agricultural and animal-breeding economy and with advanced handicrafts: the Kyrgyz Khaganatein in the upper reaches of the Yenisei river, the Uygur Khaganate, Volga Bulgaria, Alania, the Khazar Khaganate, and Hungary.

\section{THE "IMAGO" STAGE IN THE DEVELOPMENT OF THE STEPPE EMPIRES}

In terms of ontology, nomadic empire underwentacertain developmentintimeand space due to the improvement of governance methods and ways of natural resources' development and management techniques. Early forms of the steppe empires were replaced, in the first half of the XIII century, by a Mongolian Empire of Genghisides, representing a definitive stage ("imago") of the nomadic state formations. Expansion of the Mongol-Tatar super ethnos began since 1206 when Temujin was bestowed with the title of supreme khan under the name of "Genghis Khan". He succeeded to create a huge state stretching from China to Southern Rus and encompassing almost the whole steppe and forest-steppe space of Northern Eurasia as well as the bordering countries. The Mongolian nomads' camps represented "kurens", i.e. several hundred kibitkas (nomad tents) that were arranged in the form of a ring. Such mobile Mongolian camps could move freely across the huge steppe expanses and had an immense influence on the local flora and fauna, contributing to a concentration of synanthropic species as well as to the transport of intruding plants from some regions to others.

At the same time, traditionally, the camp rules, followed by Mongolian people, imply that the place of the abandoned camp must not bear any traces of human activity. In the event that a nomad camp had to be abandoned, all elements of "economic space", together with the dwelling, were transported to the new nomad camp [Tserenkhand, 1993, p.31]. The religious beliefs of Mongolian people in the past regarded the Earth as the goddess (Delkhein ezen - "Master of the Earth (Universe)"), and her body was identified with the terrestrial surface. There were a number of prohibitions to be adhered to, such as: "scratching the face of the Earth" was not permitted, i.e. digging the soil, picking flowers and grass, and moving stones. Even paths and roads were so configured that damage done to the soil was kept to a minimum [Kulpin, 2004; Nanzatov, 2008]. We are therefore justified in viewing the influence by the Mongols on the natural environment as a sufficiently positive cultural transformation of space. The Mongols, like other peoples of the Altaic language family (the Buryat, the Japanese, and the Korean) animated all natural phenomena, objects, and elements. Historically formed steppe landscape was a sacred place for them. For the first time in the world, the environmental code of laws "Yasa" was codified under Genghis Khan on the basis of the traditional Mongolian tribal law, which regulated all relations in the nature- society- people system. "Yasa" imposed punishment for the damage to natural objects more severe than for the damage to individuals. Environmental aspects of the earlier or similar laws, such as "The Laws of Hammurapi", "Salic True", and "Russian Truth", demonstrated resource-based approach to natural objects. Mongolian ":Yasa" was based on the biosphere approach: awareness of the unity of nature, society, and man.

The empire of Mongol-Tatar super-ethnos existed for about a century and then, again (as was the case with its predecessors) started to disintegrate into separate UlusHordes (Golden Horde, White Horde, Chagatai Horde, and others). Toward the mid-XV century, the Golden Horde decayed into several new Turkic states: Crimean, Kazan, Astrakhan, Siberian, and Kazakh Khanates, and also the Great Horde (in the steppes between the Volga and the Dnieper), and the Nogai Horge (in the lower and middle parts of the Yaik river basin). The last nomadic empire of the Great Steppe, the Nogai Horde, ceased its existence under Cossack attacks by the late XVI century [Trepavlov, 2002]. 
The influence of nomadic peoples on the natural environment of the steppe in the epoch of the Golden Horde still remains to be researched. Numerous settlements, including medieval towns and fortifications, which provide evidence of the sedentarynomadic lifestyle of peoples living at that time, are still not researched. In addition to nomadic and semi-nomadic animal husbandry in the steppe, the Middle Age witnessed the pursuits of distant pastures use by animal husbandry, valley-meadow and stalled keeping of livestock, and sedentary animal husbandry with footloose grazing. Among the progressing pursuits, the following can be mentioned: mining of building materials, handicrafts, and agriculture, including irrigation. Steppe settlements of the urban and rural type of the Middle Ages are currently represented by barely noticeable ruins or are occupied by contemporary residential centers, including major cities (such as Saratov, Volgograd, Orenburg, Uralsk, Ufa, Chelyabinsk, and others) and the date of their establishment is considered to be the time at which Russian or Cossack fortresses were built. Such a component of the steppe as the manymillion herds of wild ungulate animals was almost entirely replaced by domesticated livestock of about the same number.

\section{AGRICULTURAL INTERVENTION IN THE DECLINE OF THE NOMADIC EMPIRES}

China, Russia, and the Ottoman Empire were gradually involved in the re-division of lands owned by mobile stock-breeders. Extensive, mobile animal husbandry in its traditional form no longer facilitated the preservation of nomadic state entities. As the Russian state was developing, Cossack fortification lines were set up, particularly along the rivers and the Empire's borders. In the mid19th century, these lines stretched from the Dniester region to the Amur river and the Ussuri region. Like the Qin Empire that built the Great Wall of China, Russia set up fortified border lines in its southern border aimed not so much at the defense from warlike nomads, as at the "pacification" of them (Fig. 2). The rulers of Russia were aware that nomadic animal husbandry was not only a means of production, but also the lifestyle; they arranged the invasion of the bearers of agricultural traditions to the areas of habitation of the nomads and consistently pursued the anti-nomadic colonial policy [Khazanov, 2002].

This policy was continued in the form of the resettlement initiatives of the Russian Empire in the XIX and early 26XX centuries and the compulsory introduction of the settled lifestyle among nomadic peoples (compulsory sedenterization) at the time of collectivization (the 1930s). The final stage aimed at wiping the nomadic lifestyle off the face of the Eurasian steppes was implemented during the Soviet Virgin Lands Campaign (1950s-1960s) [Chibilev, 1990, 2004; Chibilev, Levykin, 1994].

During many centuries, the steppe was the springboard for campaigns, the field for small-and large-scale battles. A plain surfaced steppe is a perfect ground for a "shoot-out" between troops. On steppe battlefields the following events took place: the battle of the Kalka river, the Kulikovo battlefield, the Kosovo battlefield, the battle on Kondurcha where Timur and Tokhtamysh fought, and even Borodino and Prokhorovka battlefields. Ironically, the steppe still performed vital military-technical functions also in the 20th century. Kapustin Yar in the Lower Volga, "Shikhany" and Engels firing ranges near Saratov, Donguz firing range near Orenburg, and Emba and Semipalatinsk firing ranges in Kazakhstan are the largest steppe and desert steppe firing yards corresponding to the so called belligerent landscapes of nowadays with their trenches, including many kilometers of long ones, caponiers, and fields of bombing craters. It is the steppe fusilladed with rockets and shells; it is the steppe that is pyrogenic because of almost yearly occurring fires.

Hence, for almost twenty centuries, from Xiongnu State entities to the Nogai Horde, the Great Steppe underwent a powerful 


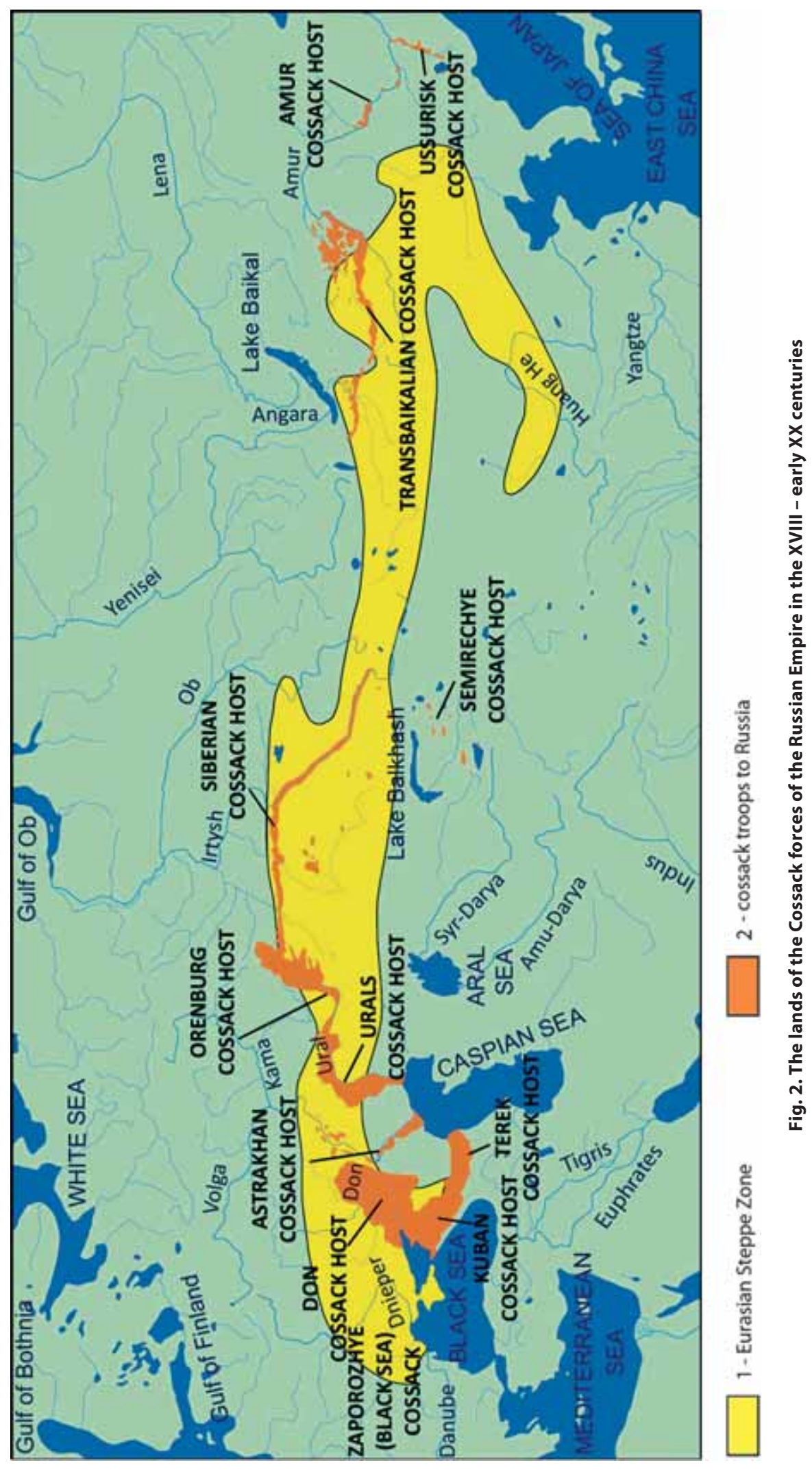


influence from alternating steppe empires, which determined the appearance of the Eurasian steppe witnessed by the naturalists of the XVIII-XIX centuries, and by the first immigrants from European provinces of Russia. It is evident that neither in the XVIII century nor in the XIX century, our predecessors could certainly see virgin steppe. The co-evolution of the Northern Eurasian nature and humans in the second half of the Holocene resulted in the steppe that was substantially altered by many centuries of influence by nomadic and seminomadic semi-settled peoples of the steppe empires.

- It is for many times scorched as well in military purposes as to herbage renovation;

- It is covered with transcontinental and local beaten tracks and caravan ways;

- It bears numerous traces of summer and winter quarters and headquarters of nomads;

- It has huge number of sacral and burial monuments. All well visible tops of hills, reference points, and outstanding cliffs over valleys were used for kings' and commons' burials (there are hundreds of thousands of such in the Great Steppe). There are piles of stones ("obo", small fences, cromlechs, and menhirs), mazars, and mausoleums, and also anthropomorphous sculptures ("stone images") and kulpytas steles.

- Its fauna is very altered. There are no large herds of wild horses, koulan, saiga, and other four-legged nomads. In years and decades of peace, herds of domesticated animals, such as horses, sheep, goats, and cattle propagated in steppe space.

Nomadic and semi-nomadic animal husbandry that was dominant in open spaces of the steppe empires constituted an integrating factor for plain ecosystems. The population and composition of livestock was controlled by seasonal weather fluctuations, dzhuts, and by other acts of God [Mordkovich, 2007; Khazanov, 2002].

According to estimations, under fluctuations of the Great Steppe human population within the range of 5-12 million people one pastured on this space at least 25-30 million horses, over 10 million cattle, up to 80 million sheep and goats together. The mechanical influence on steppe landscapes by these herds of many million domesticated animals whose character of grazing substantially differed from the wild ungulates (saiga, koulan, tarpan, etc.) is not difficult to imagine.

Since the nomadic peoples were constantly moving within their life space, they developed unique methods of managing pasture steppe areas by combining the two main principles: the linear dynamical principle and the concentric principle. The territories were dynamically affected by advanced nomads "through the division of the territory into segments... as parts of space with a particular economic activities carried out in each part... and each part characterized by a certain type of pastures" [Nanzatov et al., 2008, c.254].

The principles of concentric mastering of space, as traditionally used by TurkicMongolian nomadic peoples, were implemented in the form of their dwelling (yurta), the arrangement of camps, winter quarters, places for their carriages, and in planning and terminological designation of their nomadic route in the form of a circle. The circle meant the route of traditional roaming [Shinkarev, 1981]. Orbital distribution of pastures for different kinds of livestockaround a nomad camp is still true for nowadays regions of pasture animal husbandry in Russia, Kazakhstan, and Mongolia. It is the concentric principle of territory organization and a specific landscape land management of pasture steppe lands that predetermined the "circle" as the shape-forming origin of the nomads' ideas of the world surrounding them and that reflected their aspiration to live in concord and harmony with Nature. 


\section{DISCUSSION AND CONCLUSION The legacy of the steppe empires - the benefit or burden?}

1. After the disintegration of culturalhistorical continuums of the Early Metal Age and the early Iron Age, individual nomadic state entities, steppe empires, were appearing in the steppe belt of Eurasia since the creation of Hun Empire until the fall of the Nogai Horde and the formation of the Jungar Empire. All of them had, in terms of scale and systematic manifestations, a phenomenal quality of continuity, i.e. sustainable unity of natural and anthropogenic geosystems. The presence of continuity indicated the achievement of relative equilibrium of natural ecological and socio-cultural systems.

2. For many centuries, especially in the period of relatively peaceful development of steppe empires, their peoples (mainly of Turkic-Mongolian origin) caused a cultural transformation of space based on the sacralization and dynamical and concentric mastering of their lands. The steppe code of laws"Yasa"formed around the early XIII century, became the world's first environmental code of laws based on the paradigm of an absolute priority of nature and society (understood as a part of nature) over a personality and a man.

3. Conquest campaigns and migrations of nomads that, with natural periodicity radically changed political borders across the entire Eurasian continent, are similar not only in the means of production (nomadic and seminomadic animal husbandry) and the lifestyle of peoples of the steppe empires, but also in the natural and geographic processes. The life of every great conqueror was too short to conquer the entire Eurasia; the emperor successors inevitably lost their territories lying outside the steppe belt, broke down the legacy into uluses, creating greater and greater number of ethnic and cultural groups while maintaining the overall economic and cultural continuity. The emergence of a new charismatic leader in one of these groups eventually led to the formation of a new steppe empire.
4. Landscapes of the steppe belt of Northern Eurasia, before the beginning of agricultural development in the XIX$X X$ centuries, were sustainable naturalanthropogenic complexes formed as a result of diverse influence by nomadic and semi-nomadic peoples during the previous centuries. Naturally and geographically, the formation of nomadic empires was a result of co-evolution of the nature and men of steppes in the second half of the Holocene in the pre-industrial times. The axiom about the growing anthropogenic desertification of steppe landscapes as a result of the impact of the nomadic cattle overgrazing can not withstand serious criticism. It is based on a number of individual episodes (isolates trapped, by the political or economic reasons, in the closed ecological niches will inevitably destroy these niches, like the Bukeyev Horde in Ryn Sands in the second half of the XIX century) and on the aberrations in perception of the nomadic world by settled agricultural population. Analysis of geo-ecological situation of the Aral-Caspian basin in New Ages shows that catastrophic processes in many ways are reminiscent of the Aral Sea tragedy that occurred in the mid XVIII century - the mid XX century when, after the defeat of the Junggar Empire by China, the population density and the number of livestock in the region were the lowest over the last millennium. During this time, the Turgay, Irgiz, Emba, and many other rivers became drainless watercourses; and the lake Aksakal - Barby and dozens of other large lakes turned into salt marshes and sandy semi-deserts.

5. The task to discern consequences of multicentennialinfluencebynomadsontheformation of open landscapes (steppe, mountain steppe, forest-steppe, and desert steppe) in Eurasia is set for the modern science. The task could be solved within the frameworks of new fields of knowledge: the historical geoecology and the historical steppe science.

6. Eurasian states, first of all, Russia, Ukraine, Kazakhstan, Iran, and Turkey, are successors of nomadic steppe empires of Northern 
Eurasia. The potestative system of the state power organization, the imperative of personality subordination to higher interests of the state, economical institutions, and administrative and territorial structure of these countries inherited features of the Turkic-Mongol and the Iranian-speaking nomadic empires in their many aspects.

What is the legacy of the steppe empires for Eurasian countries; is it a blessing or a burden? Recent investigators do not have a certain answer to this question. Exaggeration of individual cultural and historical events at the end of XX century on the territory of the Eurasian space, especially the collapse of the Soviet Union, resulted in extremely pessimistic assessments by many authors. For example, the modern Russian culture experts followed by political scientists, historians, and geographers, developed a geocratic theory, i.e., the transcendent power of the Eurasian space over the states and societies in steppes of Northern Eurasia [Zamyatin, 2011. pp. 5-53]. The failure of Stalin's plan "conquest of nature" and of the post-soviet modernization projects were natural and resulted from their environmental apriority. Projects for the optimization of economic and demographic policies in the steppes of Northern Eurasia should be based on the paradigm of maintaining geosystem equilibrium including the anthropogenic component. The over seven thousand years experience in effective pastoral land use in the area is perhaps the most valuable legacy of the steppe people and empires.

\section{ACKNOWLEDGEMENT}

This work is done with financial support from the Russian Foundation for Basic Research (10-05-00867; 10-05-96056r_Ural_a).

\section{REFERENCES}

1. Adji, M. (1998) Europe, Turkic, the Great Steppe. Moscow: Mysl, 334 p.

2. Bogdanov, S.V. (2004) The Copper Epoch in the Steppe Priuralia. Ekaterinburg, 288 p.

3. Chernykh, E.N. (2007) Kargaly: The Phenomenon and the Paradoxes of its Development (Kargaly V). Moscow, $200 \mathrm{p}$

4. Chibilev, A.A. and Levykin, S.V. (1994) The Landscape-Ecological Consequences of Development of Virgin Lands on the Left Bank of the Volga and Kazakhstan. // Abstracts of papers to the Scientific-Practical Conference dedicated to the $40^{\text {th }}$ Anniversary of virgin lands upturned. Orenburg, p. 52-54.

5. Chibilev, A.A. (1990) The Face of The Steppe: Ecologo-Geographical Notes on the Steppe Zone of The USSR. Leningrad: Gidrometeoizdat, 191 p.

6. Chibilev, A.A. (2004) The Lessons Taught by Virgin Soil Upturned // Science. Society. Man. Vesnt. UrO RAN, № 3, pp. 109-116.

7. Dovatur, A.I., Kallistov D.P., Shishova I.A. (1982) Peoples of Our Country in "The History by Herodotus". Moscow, 455 p.

8. Georgi ,I.G. (1776) The Description of All Peoples Living in the Russian State. Pt. 1. SPb: Schnor. 
9. Grousset, R. (1939) L'empire des Steppes. Paris.

10. Gumilev, L.N. (2007) Ethnogenesis and Biosphere of the Earth. M., 556 p.

11. Janse, O. 1935) L'empire des steppes et Les relalions entre L'Europe et L'Extreme-Orient dans L'Antiguite'// Revue des Arts Asiatigues. Paris, T. IX. P. 9-26.

12. Khazanov, A.M. (2002) The Nomads and the Outer World. $3^{\text {rd }}$ enlarged edition. Almaty: Dyke-Press, $604 \mathrm{p}$.

13. Klyashtorny, S.G. and Savinov D.G. (2005) The Steppe Empires of Ancient Eurasia. SPb: St. Petersburg University Publisher, 346 p.

14. Krivosheyev, Yu.V. (Ed.) (2006) Russia and the Steppe World of Eurasia: Essays. SPb: St.Petersburg University Publisher, 432 p.

15. Kulpin, E.S. (2004) The Civilization of the Golden Horde. // The Mongolian Empire and the Nomadic World. Ulan-Ude, pp. 167-186.

16. Mayskiy, I.M. (1959) Mongolia on the Eve of The Revolution. Moscow: Izdatelstvo vostochnoy literatury, 158 p.

17. Merpert, N.Ya. (1974) The Oldest of Ancient Stock-Breeders of the Volga-Ural Interfluve. Moscow, $152 \mathrm{p}$.

18. Mirza Mohammad Haidar Dughlat. The Taridh-i-Rashidi. (1895) A History of the Moghuls of Central Asia. Ed. by N. Elias. Translation by E. Denison Ross. London, Sampson Low, Martston and Co.

19. Mordkovich, V.G. (2007) Siberia through the Lens of Centuries, Lands, and Peoples: Studies of the Region's Ethnoecological History. Novosibirsk: Izdatelskiy dom "Sova", 396 p.

20. Nanzatov, B.Z., Nikolayeva, D.A., Sodnompilova, M.M., Shaglanova, O.A. (2008) The Space in the Traditional Culture of Mongol Peoples. The Institute of Mongol, Buddhism, and Tibet science of the SB RAS. Moscow: Izdatelstvo vostochnoy literatury, 341 p.

21. Rudenko, S.I. (1969) Studien Liber das Nomaden tum. Jn.Viehwirtschaft and Histenkultur. P. 19-32.

22. Ryndina, N.V., Degtyareva A.D. (2002) The Aeneolithic and the Bronze Age. Moscow.

23. Savitsky, P.N. (1927) Geopolitical Notes on Russian History. Supplement to G.V. Vernadsky's book "An Outline of Russian History". Pt. 1. Prague, Eurasian Book Publisher, pp. 303-331.

24. Shinkarev, L.I. (1981) The Mongols: Traditions, Reality, and Hopes. Moscow: Sov. Rossiya, 253 p.

25. Trepavlov, V.V. (2002) The History of the Nogai Horde. Moscow: "Vost. Lit-ra" RAN, 752 p.

26. Tserenkhand, G. (1993) The Mongolian Tradition of a Nomad Camp. // From The History of The Economy and Material Culture of Turkic-Mongolian Peoples. Novosibirsk, pp. 62-74. 
27. Vernadsky, G.V. (1927) An Outline of Russian History. Part 1. With the supplement of the "Geopolitical Notes on Russian History" by P.N. Savitsky. Prague: Eurasian Book Publisher.

28. Zamyatin, D.N. (2011) Geocratic. Eurasia as an image, a symbol, and a project of Russian civilization // The state ideology and values in public policy and management. Moscow: Scientific Expert, Issue 3. pp. 5-54.

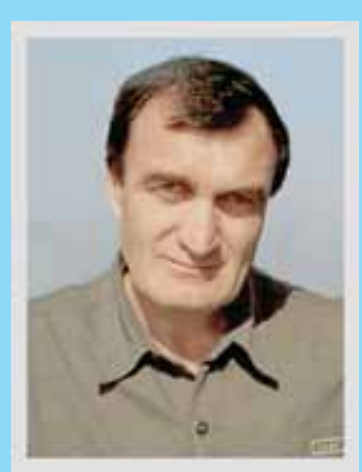

Alexander A. Chibilev is a geographer and a landscape scientist. He developed the theoretical base of the historical steppe science as the integral school in the modern geography generalizing data from natural sciences and humanities about geosystems of Northern Eurasia that combine natural and anthropogenic origins. He is the founder of the natural reserve "Orenburgskiy" that is the first steppe reserve in Russia, and also the founder of the national park "Buzulukskiy Bor." He is the Doctor of Geography (since 1992), a correspondent member of the RAS (since 1997). In 2005, he was elected vice-president of the Russian Geographical Society. He is the head of the Institute of Steppe of the Urals branch of the RAS. He is the author of over 600 publications including the monograph "The fundamentals of steppe science" (1998), "The steppe free from borders" (2003), "The landscapes of the Urals-Caspian region" (2006), "The Ural river basin: its history, geography, and ecology" (2008), "The Ural mountains as the border of Europe and Asia" (2011).

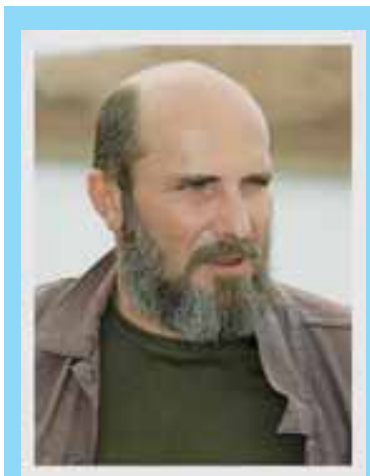

Sergey V. Bogdanov is an archaeologist and a historian steppe scientist. His scientific interests are related to the study of the heritage of nomadic cultures of Northern Eurasia. He is the Candidate of History (1999) and docent of archaeology. He heads the Laboratory of historic cultural and natural heritage of the Institute of Steppe of the Urals branch of the RAS. He is the author of over 70 scientific publications including monographs and editions "The Copper Epoch in the steppe Priuralia" (2004), "Topographiya Orenburgskaya by P.I. Rychkov" (2010), etc.

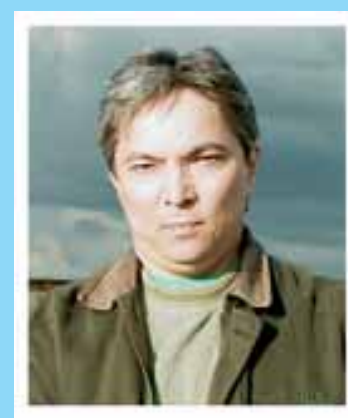

Murat N. Sdykov is a historian, a demographer, a sociologist, and president of The Kazakhstan demographists association; Doctor of History, professor. The main research interest is the historical and social cultural problems of population migrations. He held the position of the rector of The Utemisov Western Kazakhstan University till 2003. He is the head of the Western Kazakhstan Center for the History and Archaeology and the editor of "The questions of history and archaeology of The Western Kazakhstan" journal. He is the author of over 100 publications and 5 monographs, including "The history of population of the Western Kazakhstan (XVII - early XX)" published in Almaty in 2004. 